\title{
DAILY VERTICAL VARIATION IN PHYTOPLANKTON COMPOSITION OF A DRINKING WATER RESERVOIR (KADIKÖY RESERVOIR-EDİRNE) DURING SUMMER STRATIFICATION
}

\author{
Burak ÖTERLER \\ Trakya University, Faculty of Sciences, Department of Biology, 22030, Edirne, TURKEY \\ e-mail: burakoterler@trakya.edu.tr
}

Cite this article as:

Öterler B. 2018. Daily vertical variation in phytoplankton composition of a drinking water reservoir (Kadıköy Reservoir-Edirne) during summer stratification, Trakya Univ J Nat Sci, 19(1): 21-31, DOI: 10.23902/trkjnat.356711

Received: 21 November 2017, Accepted: 28 December 2017, Online First: 28 December 2017, Published: 15 April 2018

\begin{abstract}
This study is performed in August 2012 in Kadıköy Reservoir in Keşan district of Edirne. The deepest point of the reservoir when there is no water drown was chosen as the sampling station. Samples were taken from 6 different depths every three hours during a 24 hour period. 65 phytoplanktonic algae taxa belonging to Chlorophyta (26 taxa), Bacillariphyta (18 taxa), Euglenophyta ( 8 taxa), Charophyta (5 taxa), Cyanophyta (4 taxa), Miozoa (3 taxa) and Ochrophyta (1 taxa) were identified.
\end{abstract}

Key words: Phytoplankton, Daily vertical composition, Chlorophyll-a, Kadıköy Reservoir.

Özet: Bu çalışma Ağustos 2012 tarihinde Edirne ili Keşan ilçesinde bulunan Kadıköy barajında yapılmıştır. Barajdan su çekiminin yapılmadığ 1 tarihler içerisinde en derin noktası istasyon olarak seçilmiştir. Çalışma süresince 3'er saat ara ile 24 saatlik bir periyotta ve 6 farklı derinlikten örnekler alınmıştır. Çalışma süresince Chlorophyta (26 taxa), Bacillariphyta (18 taxa), Euglenophyta (8 taxa), Charophyta (5 taxa), Cyanophyta (4 taxa), Miozoa (3 taxa) ve Ochrophyta (1 taxa) divizyolarına ait toplam 65 fitoplanktonik alg taksonu belirlenmiştir.

\section{Introduction}

Reservoirs are generally formed with barriers in front of rivers and they are described as hybrid systems between the lakes and the rivers (Thornton et al. 1990). Being described as artificial lakes for different purposes like flood control, power generation, irrigation and recreation, reservoirs are separated from natural lakes with some of their characteristics like high water flow velocity, solid matter presence in influent suspend and short term water exchange (Harper et al. 1999). Naturally, as a result of changing environmental factors and irrigation activities, there might be some changes on the organisms living in an aquatic ecosystem (Wetzel 2001). The responses of the organisms affected by these changes would be either as disappearing or increasing in a population (Wetzel 2001, Harper et al. 1999). Therefore, aquatic systems must be under scientific control and physical, chemical and biological characteristics should be recorded.

As algae live in a wide range, they are the most important oxygen source of their environment and they provide oxygen and food requirements for many organisms, ranging from benthic invertebrates to fishes, in aquatic ecosystems (Round 1984). In addition to their surface distributions on the water body, it is also important how algae distribute vertically in the water column in different depths. Turbidity occuring as a result of excess increase on some water layers depending on some environmental factors (food substances, water temperature, climate condition etc.) will also suppress the community structure of the species in the lower layers (Reynolds et al. 2002, Akçaalan et al. 2006, Akçaalan et al. 2014, Becker et al. 2009). To understand the factors regulating the key species in aquatic environments, it might be important to determine daily and vertical distributions of phytoplankton communities (Takamura \& Yasuno 1984). Phytoplanktonic organisms have remodelled their morphology and physiology for surviving in different environments (Reynolds 1988), including adaptations to particular daily and vertical dynamics.

This study is performed to determine the daily vertical distributions of phytoplankton in Kadıköy Reservoir which provides tap water to Keşan district of Edirne.

\section{Materials and Methods}

\section{Study area}

Kadıköy Reservoir is located in Keşan city borders in Edirne province and was constructed in 1973 on Derbent 
Stream in order to provide water both for agricultural irrigation and industrial and daily use and to prevent flood. The reservoir is located at an altitude of $74 \mathrm{~m}$ a.s. 1 and its surface area is $6.20 \mathrm{~km}^{2}$ at normal water-level. The total agricultural area using irrigation water from the reservoir covers about 4,428 hectares and the average amount of daily water use is $2 \mathrm{hm}^{3}$ (http://www.dsi.gov.tr) (Fig. 1).

The sampling station was selected near the water intake $\left(40^{\circ} 47^{\prime} 40.04^{\prime \prime} \mathrm{N}, 26^{\circ} 46^{\prime} 24.31^{\prime \prime} \mathrm{E}\right)$ in the deepest part of the reservoir. The reservoir shows the characteristics of a mesoeutrophic system and its maximum depth is $18.5 \mathrm{~m}$ (Öterler et al. 2015). The annual mean temperature is $13.5^{\circ} \mathrm{C}$. The reservoir was thermally stratified, as clear mixed epilimnion and slightly alkaline conditions. Some physico-chemical parameters were formerly measured in the water column (Öterler et al. 2015) (Table 1).

\section{Sampling and analyses}

Phytoplankton and water samplings were taken in the reservoir on 16 August 2012. Samplings started at midday (13:00) and phytoplankton communities were sampled every $3 \mathrm{~h}$ during a $24-\mathrm{h}$ period in a vertical profile. Samplings were performed from surface water and from 6 depths of $1,3,5,9,12$ and 15 meters. Samplings were made during the period when the dam covers were closed and there was no water intake.

Water samples were taken from under water surface using a Van Dorn type water sampler in order to determine some environmental values of the reservoir such as water temperature, dissolved oxygen (DO), $\mathrm{pH}$, nitrogen in nitrite and nitrate forms and phosphate values. Water temperature, $\mathrm{DO}, \mathrm{pH}$ and electrical conductivity were measured on sampling station using field type equipments and chlorophyll- $a$ was measured spectrophotometrically according to Nusch (1980). Water transparency was measured once using a $20-\mathrm{cm}$ Secchi disk.

For the phytoplankton samples, 1L of the water samples taken from the reservoir using Whatmann GF/A filter papers were filtered, planktonic samples were condensed and identification of the algae other than diatoms in temporary slides were done on Olympus brand CX41 model microscope. For identifications of diatoms, samples brought to the laboratory were purified from organic matter by boiling in 1:1 volume $\mathrm{H}_{2} \mathrm{SO}_{4}+\mathrm{HNO}_{3}$ and by rinsing in distilled water for a couple of times. Neutral $\mathrm{pH}$ was provided and a drop was taken and dried on lamella, then it was covered by Naphrax and permanent slides were prepared and identified under the microscope. From the water samples, 25-50 and 100ml sub-samples were prepared, precipitated according to Utermöhl (1958) and organism counts and calculations were done under an Olympus brand CK2 model inverted microscope. The taxonomic books (Huber-Pestalozzi 1982, John et al. 2003, Krammer \& Lange-Bertalot 19862004, Round et al. 1990, Komarek \& Anagnostidis 2005, Hindák 2008, Kristiansen \& Preisig 2011) were used for the identification of algal species. All species were checked online on algaebase cite (Guiry \& Guiry. 2017).

Table 1. Some environmental variables in the water column (Öterler et al. 2015).

\begin{tabular}{ll}
\hline \hline Parameters & Values \\
\hline \hline $\mathrm{NO}_{2}^{-}$ & $0.037 \mathrm{mg} . \mathrm{L}^{-1}$ \\
$\mathrm{NO}_{3}{ }^{-}$ & $1.778 \mathrm{mg} . \mathrm{L}^{-1}$ \\
$\mathrm{SRP}$ & $0.009 \mathrm{mg} . \mathrm{L}^{-1}$ \\
Hardness & $22^{\circ} \mathrm{F}$ \\
Salinity & $0.083 \%$ o \\
Secchi Disc & $98 \mathrm{~cm}$ (Midday) \\
\hline \hline
\end{tabular}

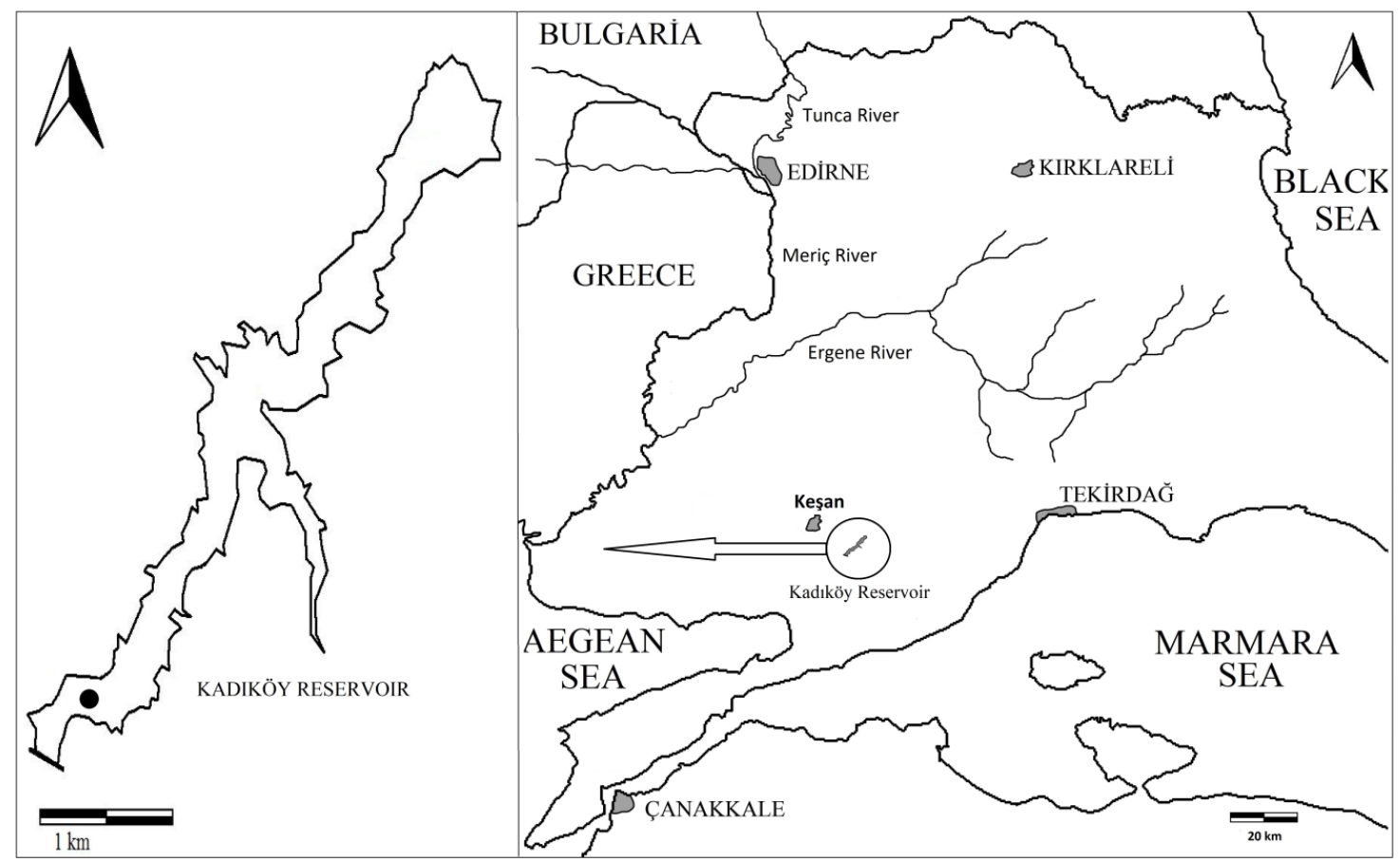

Fig. 1. The map showing the locations of Kadıköy Reservoir and the sampling point. The solid circle in the left figure corresponds to the sampling point. 


\section{Results}

The sky was open during samplings and the mean wind speed varied from 3 to $8 \mathrm{~ms}^{-1}$ depending on the sampling time. In morning samplings, generally a relatively gentle breeze occurred while evening and night time samplings were generally characterized by a moderate and a light breeze, respectively.

Air temperature was lower than surface water temperature from 22:00 to 07:00h, but higher from 10:00 to 19:00h. The daily water temperature ranged from $18.5^{\circ} \mathrm{C}$ to $27^{\circ} \mathrm{C}$, but the surface water $(0-5 \mathrm{~m})$ lost heat throughout the night when the air temperature fell below the surface water but gained heat during the day (Fig. 2).

The highest value of average DO was measured in $1 \mathrm{~m}$ samples of $04.00 \mathrm{pm}$ with $11.86 \mathrm{mg} . \mathrm{L}^{-1}$ and the descending ranking in terms of DO was as $5 m>1 m>3 m>$ Subsurface $>9 m>12 m>15$. The $p H$ was measured between 7.41 and 8.94 and conductivity average

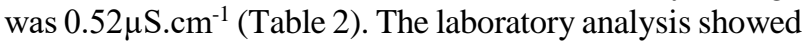
that there was no significant difference between sampling depths and times in the measured parameters.

\section{Phytoplankton species diversity and chlorophyll-a}

Identification of the sampled material showed that a total of 65 taxa were present in the reservoir during the sampling period. Chlorophyta was identified as the group having the maximum number of taxa with 26 , followed by Diatoms (Bacillariophyta) with 18 taxa, Euglenophyta with 8 taxa, Carophyta with 5 taxa, Cyanophyta with 4 taxa, Miozoa with 3 taxa and Ochrophyta with 1 taxon (Table 3).

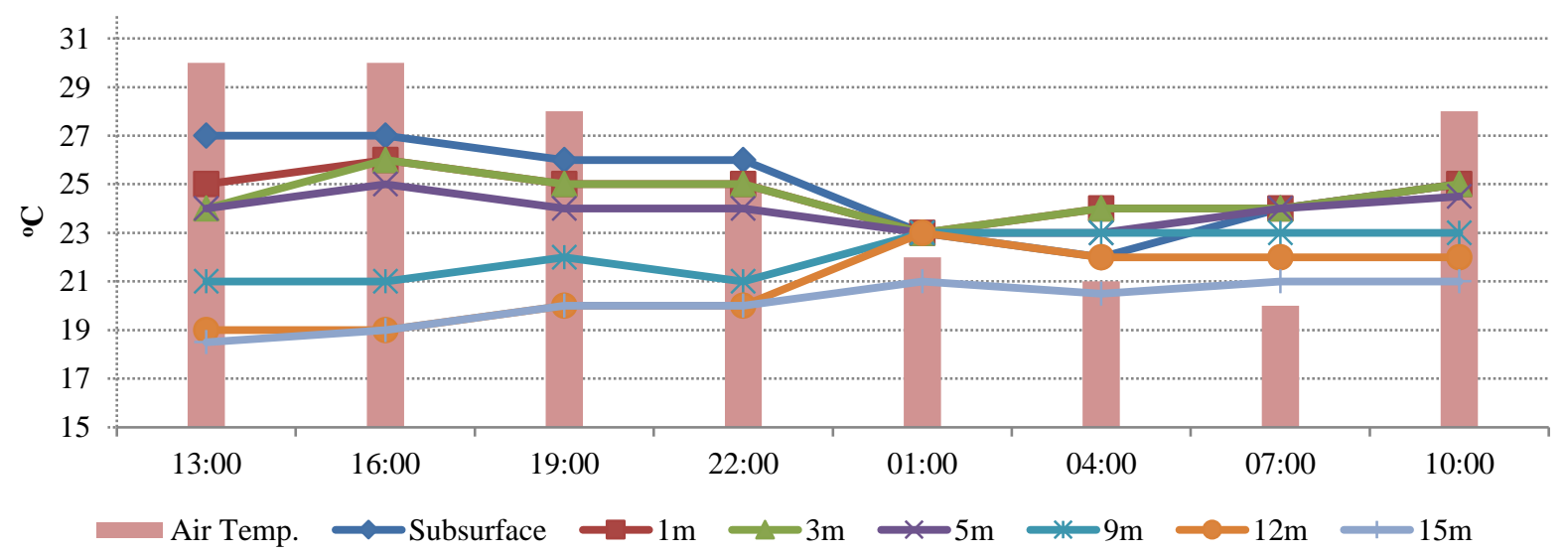

Fig. 2. The relationship between water and air temperature values during a sampling day.

Table 2. Daily variation of Dissolved Oxygen (DO) concentration (mg.L-1 $)$, pH and Electric Conductivity (EC) $\left(\mu \mathrm{S} . \mathrm{cm}^{-1}\right)$ of the water column in the reservoir.

\begin{tabular}{|c|c|c|c|c|c|c|c|c|c|}
\hline & Depth/Hours & 13:00 & 16:00 & 19:00 & 22:00 & 01:00 & 04:00 & 07:00 & 10:00 \\
\hline \multirow{7}{*}{ 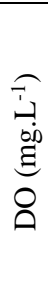 } & Surface & 7.71 & 7.09 & 6.14 & 9.92 & 9.23 & 11.71 & 9.4 & 8.6 \\
\hline & $1 \mathrm{~m}$ & 7.57 & 7.6 & 6.15 & 9.65 & 9.9 & 11.86 & 10.41 & 8.4 \\
\hline & $3 \mathrm{~m}$ & 7.54 & 7.48 & 6.28 & 9.58 & 9.64 & 11.62 & 10.58 & 8.36 \\
\hline & $5 \mathrm{~m}$ & 7.47 & 7.91 & 6.69 & 9.55 & 9.59 & 11.54 & 11.61 & 8.41 \\
\hline & $9 \mathrm{~m}$ & 7.28 & 7.35 & 6.18 & 8.84 & 9.51 & 10.75 & 11.34 & 7.32 \\
\hline & $12 \mathrm{~m}$ & 6.99 & 6.88 & 6.35 & 8.33 & 9.54 & 10.08 & 10.82 & 6.92 \\
\hline & $15 \mathrm{~m}$ & 6.5 & 4.26 & 5.24 & 7.86 & 9.63 & 10.13 & 9.94 & 6.82 \\
\hline \multirow{7}{*}{$\stackrel{T}{2}$} & Surface & 8.47 & 7.41 & 8.94 & 8.6 & 8.56 & 8.33 & 8.25 & 7.88 \\
\hline & $1 \mathrm{~m}$ & 8.24 & 8.8 & 8.9 & 8.29 & 8.6 & 8.45 & 8.25 & 7.86 \\
\hline & $3 \mathrm{~m}$ & 8.18 & 8.71 & 8.73 & 8.3 & 8.41 & 8.43 & 8.32 & 7.78 \\
\hline & $5 \mathrm{~m}$ & 8.17 & 8.58 & 8.21 & 8.33 & 8.63 & 8.52 & 8.53 & 7.76 \\
\hline & $9 m$ & 8.15 & 8.21 & 8.05 & 8.33 & 8.57 & 8.21 & 8.23 & 7.58 \\
\hline & $12 \mathrm{~m}$ & 8.12 & 8.11 & 7.79 & 8.24 & 8.27 & 8.07 & 8.14 & 7.52 \\
\hline & $15 \mathrm{~m}$ & 8.07 & 7.71 & 7.73 & 8.05 & 8.14 & 7.86 & 7.88 & 7.46 \\
\hline \multirow{7}{*}{ 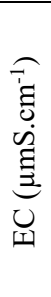 } & Surface & 0.58 & 0.54 & 0.51 & 0.51 & 0.5 & 0.5 & 0.49 & 0.52 \\
\hline & $1 \mathrm{~m}$ & 0.57 & 0.54 & 0.51 & 0.5 & 0.5 & 0.5 & 0.49 & 0.52 \\
\hline & $3 \mathrm{~m}$ & 0.57 & 0.55 & 0.51 & 0.51 & 0.52 & 0.5 & 0.5 & 0.52 \\
\hline & $5 \mathrm{~m}$ & 0.59 & 0.55 & 0.51 & 0.5 & 0.5 & 0.49 & 0.49 & 0.54 \\
\hline & $9 \mathrm{~m}$ & 0.6 & 0.55 & 0.52 & 0.51 & 0.51 & 0.51 & 0.5 & 0.54 \\
\hline & $12 \mathrm{~m}$ & 0.62 & 0.56 & 0.52 & 0.51 & 0.51 & 0.51 & 0.5 & 0.54 \\
\hline & $15 \mathrm{~m}$ & 0.64 & 0.58 & 0.53 & 0.5 & 0.51 & 0.51 & 0.5 & 0.55 \\
\hline
\end{tabular}


Table 3. The list of the planktonic algal species determined in the reservoir with respect tothe sampling depths. Represents presence of a taxon in a particular depth sample.

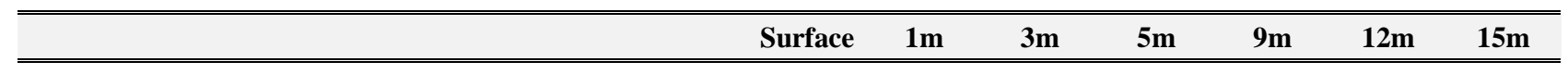

\section{BACILLARIOPHYTA}

Bacillariophyceae

Cocconeis placentula Ehrenberg

Cymatopleura elliptica (Brébisson) Smith

Cymatopleura solea (Brébisson) Smith

Cymbella cymbiformis Agardh

Cymbella tumida (Brébisson) Van Heurck

Gyrosigma attenuatum (Kützing) Rabenhorst

Hippodonta capitata (Ehren.) Metzeltin\&Witkowski

Navicula sp.

Navicula viridula (Kützing) Ehrenberg

Nitzschia acicularis (Kützing) Smith

Nitzschia palea (Kützing) Smith

Nitzschia sp.

\section{Coscinodiscophyceae}

Aulacoseira italica (Ehrenberg) Simonsen

Melosira varians Agardh

Fragilariophyceae

Diatoma vulgaris Bory

Fragilaria crotonensis Kitton

Ulnaria ulna (Nitzsch) Compère

Mediophyceae

Cyclotella meneghiniana Kützing

\section{CHAROPHYTA}

\section{Conjugatophyceae}

Closterium pronum Brébisson

Closterium sp.

Cosmarium sp.

Staurastrum paradoxum Meyen

Staurastrum punctulatum Bréb.

$\begin{array}{llllll} & X & & X & X & \\ X & X & X & X & X & \\ X & X & & X & X & X \\ X & & & & \end{array}$

$\mathrm{X}$

$\begin{array}{ccccccc} & \text { X } & \text { X } & & \text { X } & & \\ & \text { X } & & \text { X } & & & \text { X } \\ & \text { X } & \text { X } & \text { X } & \text { X } & \text { X } & \text { X } \\ \text { X } & \text { X } & \text { X } & \text { X } & \text { X } & \text { X } & \text { X } \\ \text { X } & & & & & & \\ \text { X } & \text { X } & \text { X } & \text { X } & \text { X } & \text { X } & \text { X } \\ \text { X } & \text { X } & \text { X } & \text { X } & \text { X } & \text { X } & \text { X } \\ \text { X } & \text { X } & \text { X } & \text { X } & \text { X } & \text { X } & \text { X }\end{array}$

$\begin{array}{llll}X & X & X\end{array}$

X $\quad X$

X

$X$

$\mathrm{X}$

X $\quad X \quad X$

$\mathrm{X}$

X

X

X

X

X

X

$\mathrm{X}$

X $\quad \mathrm{X}$

CHLOROPHYTA

\section{Chlorophyceae}

Coelastrum astroideum De Notaris

Coelastrum microporum Nägeli

Desmodesmus abundans (Kirchner) Hegewald

Hariotina reticulata Dangeard

Kirchneriella sp.

Monactinus simplex (Meyen) Corda

Monoraphidium contortum (Thuret) Komárková-Leg.

Monoraphidium minutum (Nägeli) Komárková-Leg.

Pediastrum duplex Meyen

Pseudopediastrum boryanum (Turpin) Hegewald

Scenedesmus bijuga (Turpin) Lag.

Scenedesmus quadricauda (Turpin) Brébisson

Schroederia sp.

Tetradesmus dimorphus (Turpin) Wynne

Tetradesmus lagerheimii Wynne \& Guiry

Tetradesmus obliquus (Turpin) Wynne

$\mathrm{X}$

$\mathrm{X}$

$\mathrm{X}$

$\mathrm{X}$

$\mathrm{X}$

$\mathrm{X}$

$\mathrm{X}$

$\mathrm{X}$

$\mathrm{X}$

$\mathrm{X}$

$\mathrm{X}$

$\mathrm{X}$

$\mathrm{X}$

$\mathrm{X} \quad \mathrm{X}$

$X \quad X$

$\mathrm{X} \quad \mathrm{X}$

$\mathrm{X} \quad \mathrm{X}$

X $\mathrm{X}$

$X$
$X$
$X$
$X$
$X$
$X$
$X$
$X$
$X$
$X$
$X$
$X$

\begin{tabular}{|c|c|}
\hline$X$ & $X$ \\
\hline$X$ & $X$ \\
\hline $\mathrm{X}$ & $X$ \\
\hline$X$ & $X$ \\
\hline $\mathrm{X}$ & $X$ \\
\hline $\mathrm{X}$ & $X$ \\
\hline$X$ & $X$ \\
\hline$X$ & $X$ \\
\hline$X$ & $X$ \\
\hline$X$ & $X$ \\
\hline$X$ & \\
\hline$X$ & $X$ \\
\hline$X$ & $X$ \\
\hline & $X$ \\
\hline X & $X$ \\
\hline$X$ & $X$ \\
\hline
\end{tabular}

\begin{tabular}{|c|c|c|}
\hline$X$ & $X$ & $X$ \\
\hline$X$ & & $X$ \\
\hline$X$ & $X$ & $X$ \\
\hline$X$ & $X$ & \\
\hline$X$ & $X$ & $X$ \\
\hline$X$ & $\mathrm{X}$ & \\
\hline$X$ & & $X$ \\
\hline$X$ & $\mathrm{X}$ & $X$ \\
\hline$X$ & & $X$ \\
\hline & $X$ & \\
\hline$X$ & & $X$ \\
\hline$X$ & & $\mathrm{X}$ \\
\hline$X$ & $X$ & \\
\hline$X$ & $X$ & \\
\hline$X$ & $X$ & $X$ \\
\hline X & $X$ & \\
\hline
\end{tabular}




\begin{tabular}{|c|c|c|c|c|c|c|c|}
\hline & Surface & $1 \mathrm{~m}$ & $3 \mathrm{~m}$ & $5 \mathrm{~m}$ & $9 \mathrm{~m}$ & $12 \mathrm{~m}$ & $15 \mathrm{~m}$ \\
\hline Tetraedron caudatum (Corda) Hans. & $\mathrm{X}$ & $\mathrm{X}$ & $\mathrm{X}$ & $\mathrm{X}$ & $\mathrm{X}$ & $\mathrm{X}$ & $\mathrm{X}$ \\
\hline Tetraedron trigonum (Nägeli) Hans. & & & $\mathrm{X}$ & $\mathrm{X}$ & & & \\
\hline Tetrastrum staurogeniiforme (Schröder) Lemm. & $\mathrm{X}$ & $\mathrm{X}$ & $\mathrm{X}$ & $\mathrm{X}$ & $\mathrm{X}$ & & $\mathrm{X}$ \\
\hline \multicolumn{8}{|l|}{ Eustigmatophyceae } \\
\hline Tetraëdriella regularis (Kützing) Fott & $\mathrm{X}$ & $\mathrm{X}$ & $\mathrm{X}$ & $\mathrm{X}$ & $\mathrm{X}$ & $\mathrm{X}$ & $\mathrm{X}$ \\
\hline \multicolumn{8}{|l|}{ Trebouxiophyceae } \\
\hline Botryococcus braunii Kützing & $\mathrm{X}$ & $\mathrm{X}$ & $\mathrm{X}$ & $\mathrm{X}$ & & & \\
\hline Chlorella sp. & $\mathrm{X}$ & $\mathrm{X}$ & $\mathrm{X}$ & $\mathrm{X}$ & $\mathrm{X}$ & $\mathrm{X}$ & $\mathrm{X}$ \\
\hline Crucigenia tetrapedia (Kirchner) Kuntze & $\mathrm{X}$ & $\mathrm{X}$ & $\mathrm{X}$ & $\mathrm{X}$ & $\mathrm{X}$ & $\mathrm{X}$ & $\mathrm{X}$ \\
\hline Dictyosphaerium sp. & $\mathrm{X}$ & $\mathrm{X}$ & $\mathrm{X}$ & $\mathrm{X}$ & $\mathrm{X}$ & & \\
\hline Oocystis sp. & $\mathrm{X}$ & $\mathrm{X}$ & $\mathrm{X}$ & $\mathrm{X}$ & $\mathrm{X}$ & $\mathrm{X}$ & $\mathrm{X}$ \\
\hline Willea rectangularis (Braun) Wynne \& Tsarenko & $\mathrm{X}$ & $\mathrm{X}$ & $\mathrm{X}$ & $\mathrm{X}$ & $\mathrm{X}$ & $\mathrm{X}$ & $\mathrm{X}$ \\
\hline \multicolumn{8}{|l|}{ CYANOBACTERIA (Cyanophyta) } \\
\hline \multicolumn{8}{|l|}{ Cyanophyceae } \\
\hline Microcystis aeruginosa (Kützing) Kützing & $\mathrm{X}$ & $\mathrm{X}$ & $\mathrm{X}$ & $\mathrm{X}$ & $\mathrm{X}$ & $\mathrm{X}$ & $\mathrm{X}$ \\
\hline Chroococcus sp. & $\mathrm{X}$ & $\mathrm{X}$ & $\mathrm{X}$ & $\mathrm{X}$ & $\mathrm{X}$ & $\mathrm{X}$ & $\mathrm{X}$ \\
\hline Merismopedia sp. & $\mathrm{X}$ & $\mathrm{X}$ & $\mathrm{X}$ & $\mathrm{X}$ & $\mathrm{X}$ & & $\mathrm{X}$ \\
\hline Oscillatoria limosa Agardh & & & & & & $\mathrm{X}$ & $\mathrm{X}$ \\
\hline \multicolumn{8}{|l|}{ EUGLENOPHYTA } \\
\hline \multicolumn{8}{|l|}{ Euglenophyceae } \\
\hline Euglena granulata (Klebs) Schmitz & $\mathrm{X}$ & $\mathrm{X}$ & & $\mathrm{X}$ & $\mathrm{X}$ & $\mathrm{X}$ & $\mathrm{X}$ \\
\hline Euglena texta (Duj.) Hüb. & $\mathrm{X}$ & $\mathrm{X}$ & $\mathrm{X}$ & $\mathrm{X}$ & $\mathrm{X}$ & $\mathrm{X}$ & $\mathrm{X}$ \\
\hline Lepocinclis acus (Müller) Marin \& Melkonian & $\mathrm{X}$ & $\mathrm{X}$ & $\mathrm{X}$ & $\mathrm{X}$ & $\mathrm{X}$ & $\mathrm{X}$ & $\mathrm{X}$ \\
\hline Phacus acuminatus Stokes & $\mathrm{X}$ & $\mathrm{X}$ & $\mathrm{X}$ & $\mathrm{X}$ & $\mathrm{X}$ & $\mathrm{X}$ & $\mathrm{X}$ \\
\hline Phacus longicauda (Ehrenberg) Dujardin & $\mathrm{X}$ & $\mathrm{X}$ & $\mathrm{X}$ & $\mathrm{X}$ & & $\mathrm{X}$ & \\
\hline Strombomonas sp. & $\mathrm{X}$ & $\mathrm{X}$ & $\mathrm{X}$ & $\mathrm{X}$ & $\mathrm{X}$ & $\mathrm{X}$ & $\mathrm{X}$ \\
\hline Trachelomonas hispida (Perty) Stein & $\mathrm{X}$ & $\mathrm{X}$ & $\mathrm{X}$ & $\mathrm{X}$ & $\mathrm{X}$ & $\mathrm{X}$ & $\mathrm{X}$ \\
\hline Trachelomonas volvocina (Ehrenberg) Ehrenberg & $\mathrm{X}$ & $\mathrm{X}$ & & $\mathrm{X}$ & $\mathrm{X}$ & $\mathrm{X}$ & \\
\hline \multicolumn{8}{|l|}{ MIOZOA } \\
\hline \multicolumn{8}{|l|}{ Dinophyceae } \\
\hline Ceratium hirundinella (Müller) Duj. & & $\mathrm{X}$ & $\mathrm{X}$ & $\mathrm{X}$ & & & \\
\hline Peridiniopsis cunningtonii Lem. & $X$ & $\mathrm{X}$ & $\mathrm{X}$ & $\mathrm{X}$ & $\mathrm{X}$ & $\mathrm{X}$ & $\mathrm{X}$ \\
\hline Peridinium cinctum (Müller) Ehrenberg & $\mathrm{X}$ & $\mathrm{X}$ & $\mathrm{X}$ & $\mathrm{X}$ & $\mathrm{X}$ & $\mathrm{X}$ & $\mathrm{X}$ \\
\hline \multicolumn{8}{|l|}{ OCHROPHYTA } \\
\hline \multicolumn{8}{|l|}{ Chrysophyceae } \\
\hline Dinobryon divergens Imhof & $\mathrm{X}$ & $\mathrm{X}$ & $\mathrm{X}$ & $\mathrm{X}$ & $\mathrm{X}$ & & \\
\hline
\end{tabular}

A total of 53 taxa were determined in the samples taken from subsurface while the taxa determined in 1, 3, 5, 912 and $15 \mathrm{~m}$ depths were 56, 53, 55, 44, 43 and 42, respectively (Fig. 3). The hourly samplings showed that the minimum and maximum taxa numbers were obtained at 19:00 (31 taxa) and at 01:00 (19 taxa) for subsurface samplings, at 10:00 (29 taxa) and at 19:00 (22 taxa) for $1 \mathrm{~m}$ samplings, at 07:00 (31 taxa) and at 22:00 (21 taxa) for 5m samplings and at 01:00 (26 taxa) and at 13:00 (12 taxa) for $15 \mathrm{~m}$ samplings (Fig. 4).

During the study, phytoplankton numbers in liter were calculated from all depths and for chosen sampling hours. The highest cell number (80790ind.L ${ }^{-1}$ ) was calculated in the sampling at 01:00 on the surface and the lowest
(19540ind.L -1 $^{-1}$ was calculated at 07:00 in 15m (Fig. 5). Average cell number and percentage distributions according to the groups in the reservoir are given in Table 4. Spectrophotometric measurements showed that the highest average chlorophyll- $a$ was measured at 22:00 for the surface sampling $\left(12.57 \mu \mathrm{g} . \mathrm{L}^{-1}\right)$ and the lowest was measured at 16:00 for $15 \mathrm{~m}$ sampling $\left(3.1 \mu \mathrm{g} . \mathrm{L}^{-1}\right)$ (Fig. 6).

Crucigenia tetrapedia, Monactinus simplex, Scenedesmus quadricauda and Coelastrum astroideum from the green algae, Peridiniopsis cunningtonii and Peridinium cinctum from Miozoa, Staurastrum paradoxum from Charophyta and Microcystis aeruginosa from Cyanobacteria were identified as the dominant organisms of Kadıköy Reservoir during the study. 


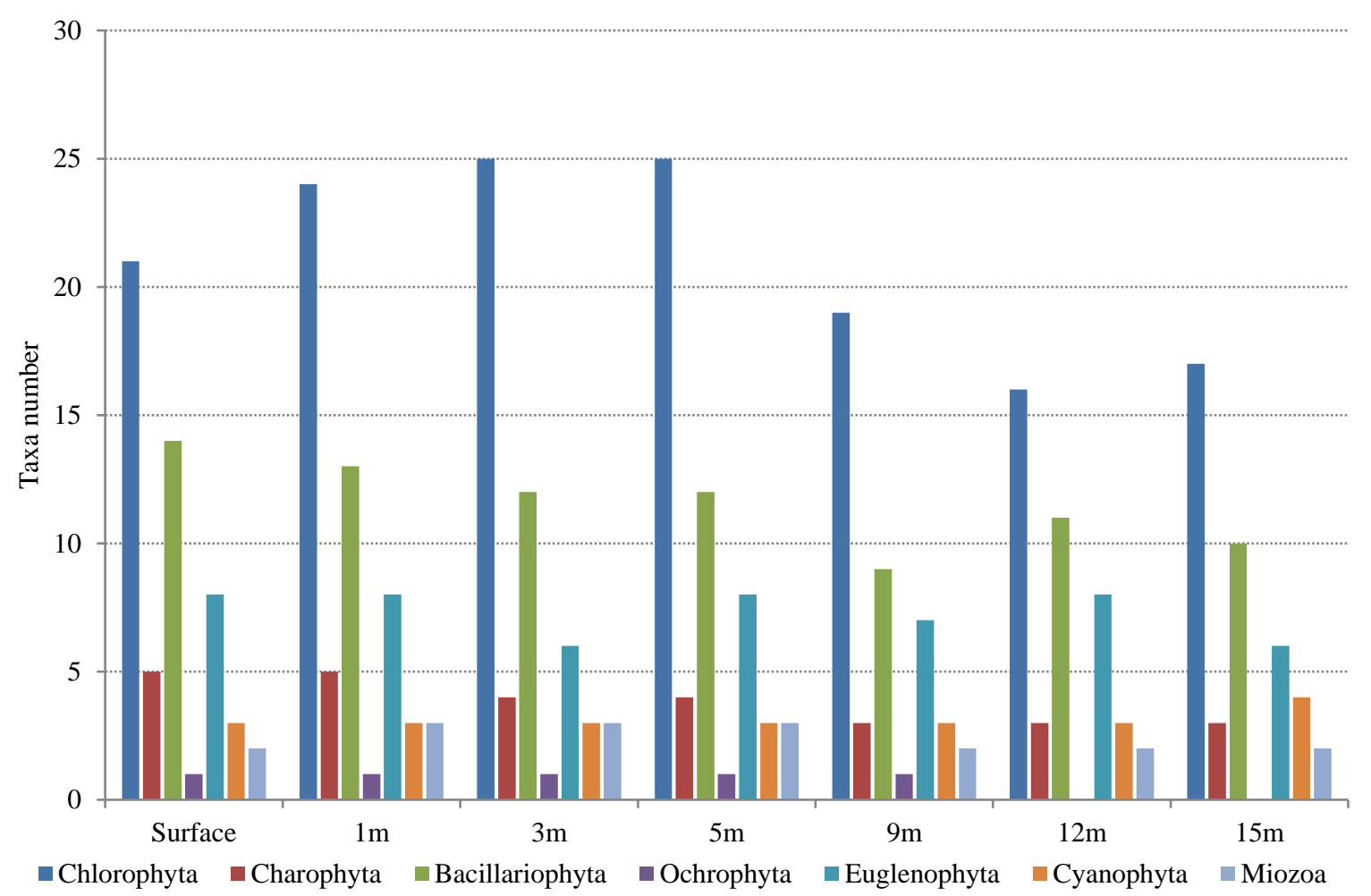

Fig. 3. The spatial distribution of phytoplankton taxa identified in the reservoir with respect to depths.

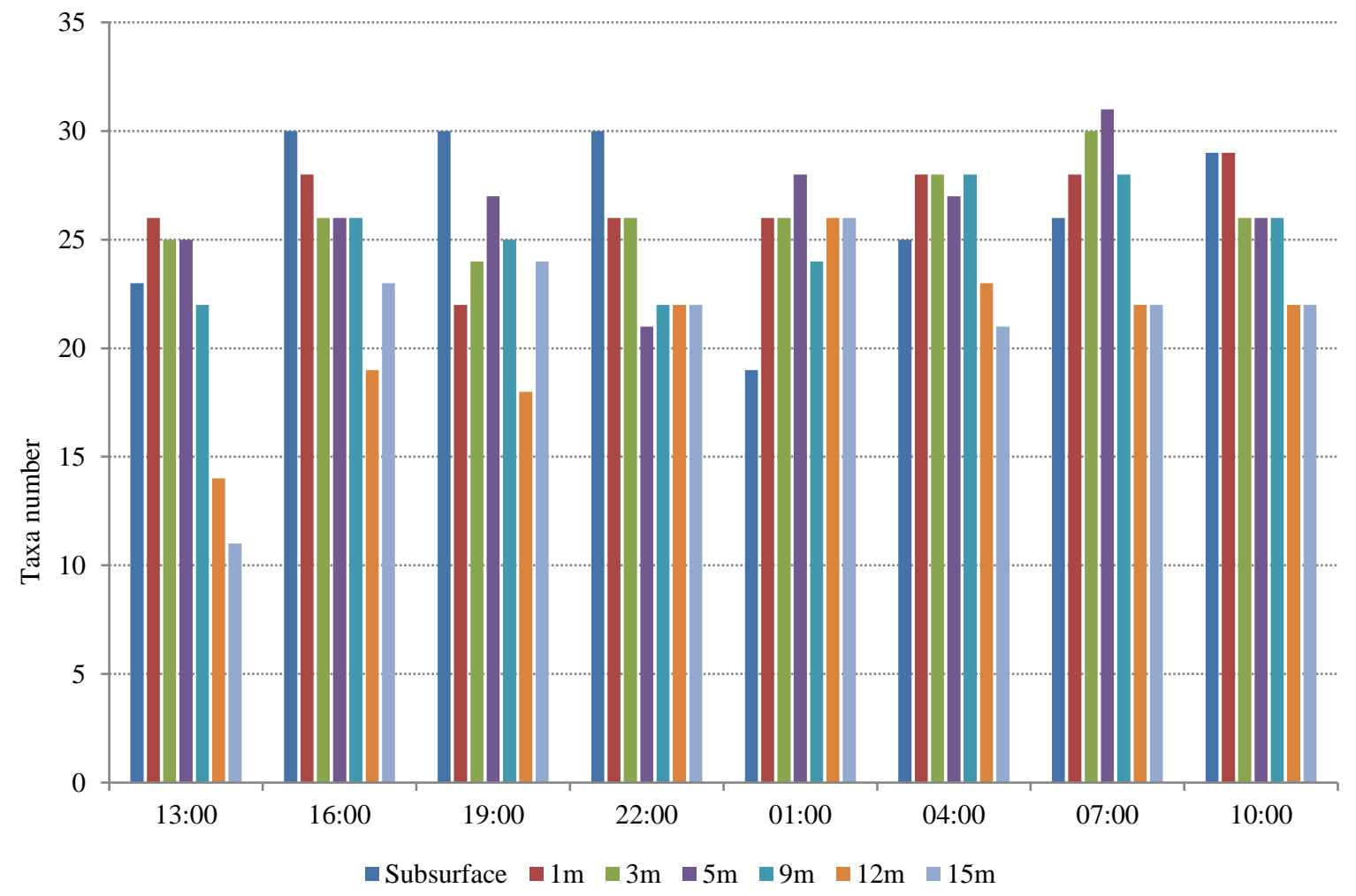

Fig. 4. The spatial distribution of phytoplankton taxa identified in the reservoir with respect to sampling hours. 


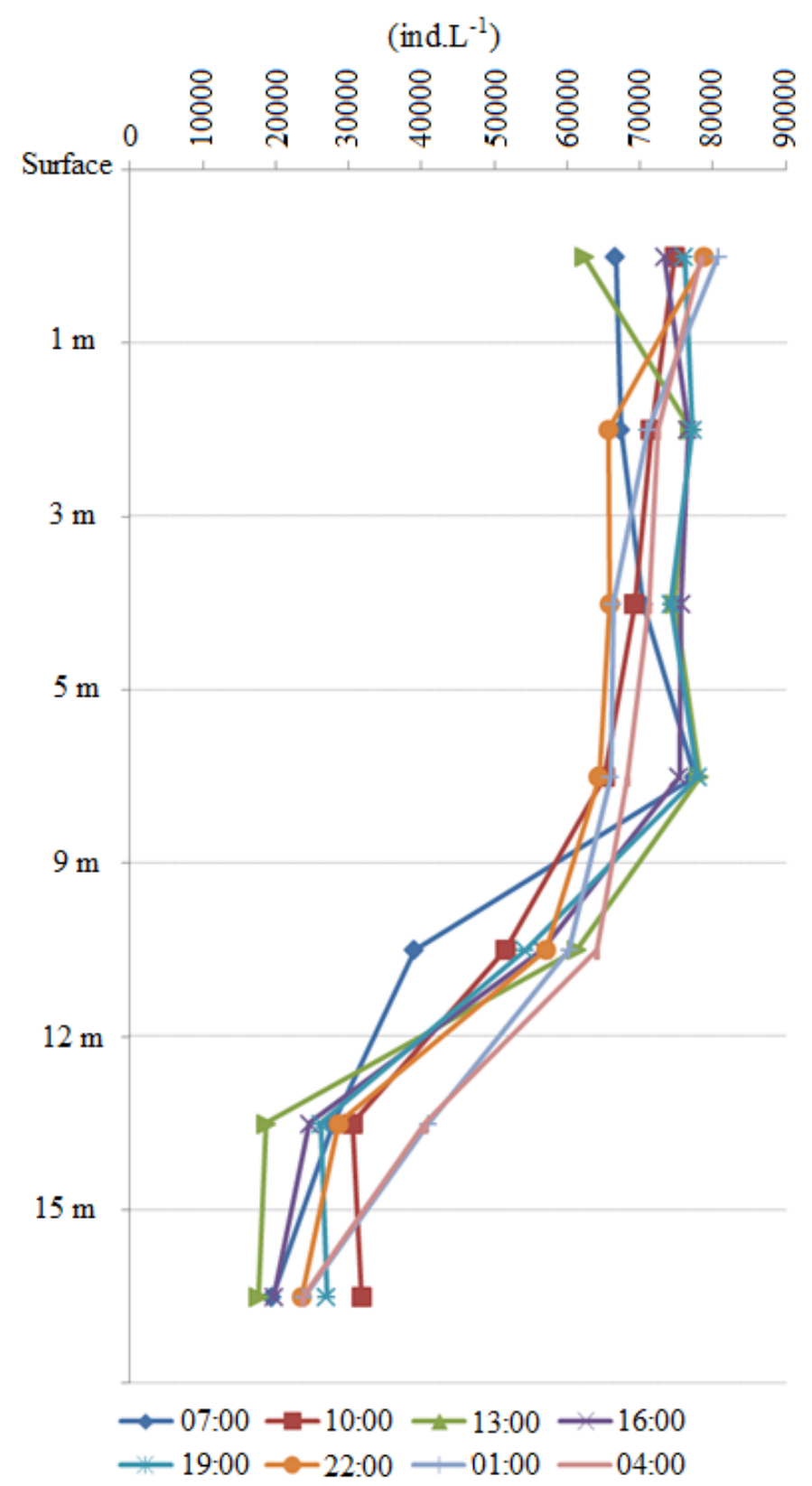

Fig. 5. Organism numbers (in total) determined with respect to depths (ind. $\mathrm{L}^{-1}$ ).

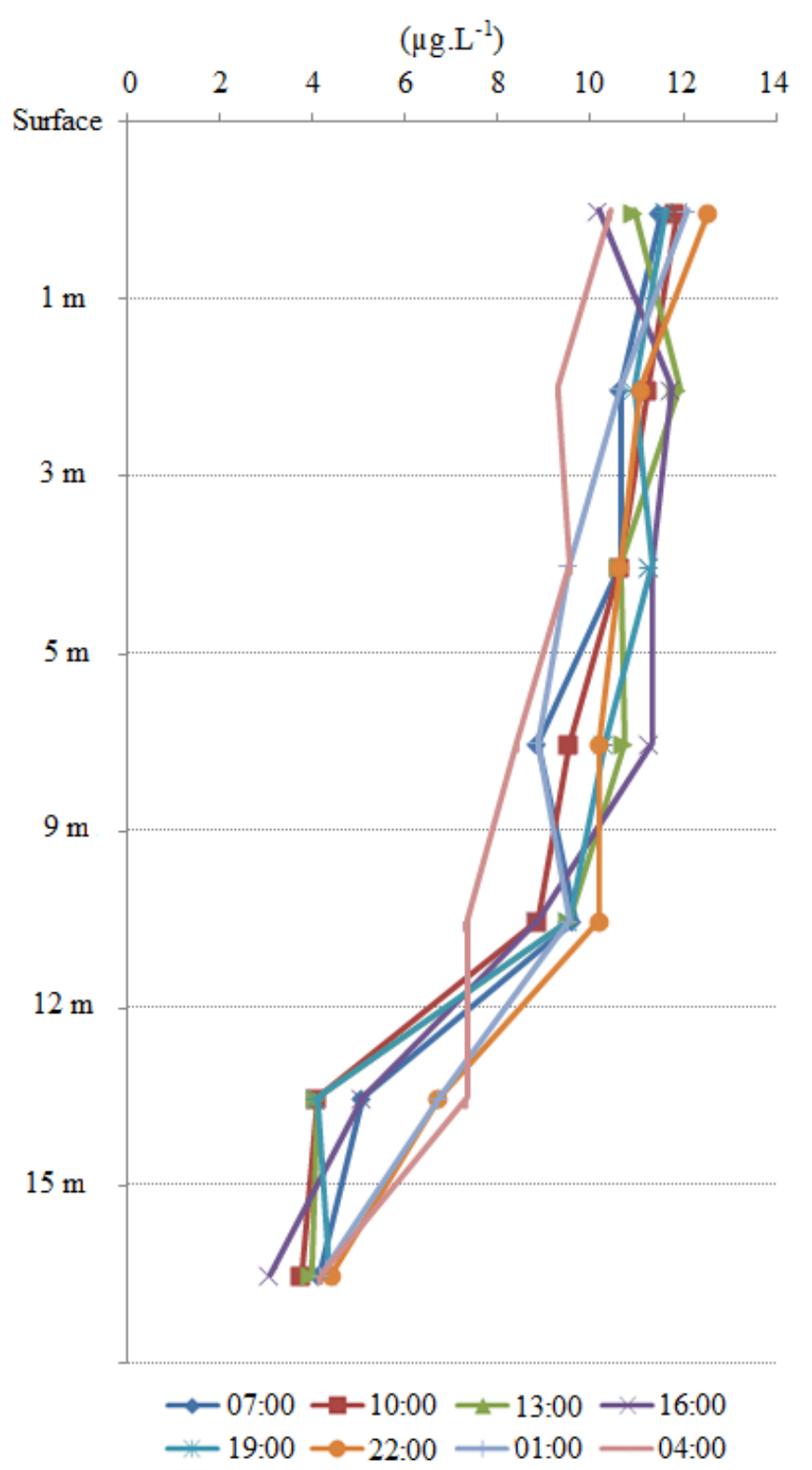

Fig. 6. Chlorophyll-a quantities identified with respect to depths $\left(\mu \mathrm{g} . \mathrm{L}^{-1}\right)$.

Table 4. Abundance of taxonomic groups of phytoplankton and their contributions to total phytoplankton abundance in the reservoir (ind. $\mathrm{L}^{-1}$ ).

\begin{tabular}{llllllll}
\hline \hline & Subsurface & $\mathbf{1 m}$ & $\mathbf{3 m}$ & $\mathbf{5 m}$ & $\mathbf{9 m}$ & $\mathbf{1 2 m}$ & $\mathbf{1 5 m}$ \\
\hline \hline Bacillariophyta & 2453 & 2051 & 2476 & 2406 & 2389 & 1806 & 1871 \\
Charophyta & 5963 & 6096 & 7012 & 6798 & 7096 & 2227 & 1745 \\
Chlorophyta & 44121 & 40662 & 40195 & 40368 & 28287 & 16912 & 13020 \\
Cyanophyta & 6461 & 6519 & 5526 & 6149 & 4994 & 2068 & 1068 \\
Euglenophyta & 3225 & 3792 & 4651 & 5103 & 2954 & 3417 & 3619 \\
Miozoa & 11733 & 13263 & 11144 & 10795 & 9825 & 3388 & 2075 \\
Ochrophyta & 6157 & 7214 & 7200 & 7886 & 8243 & 7909 & 7460 \\
Total & 80113 & 79597 & 78203 & 79505 & 63789 & 37726 & 30857 \\
\hline \hline
\end{tabular}



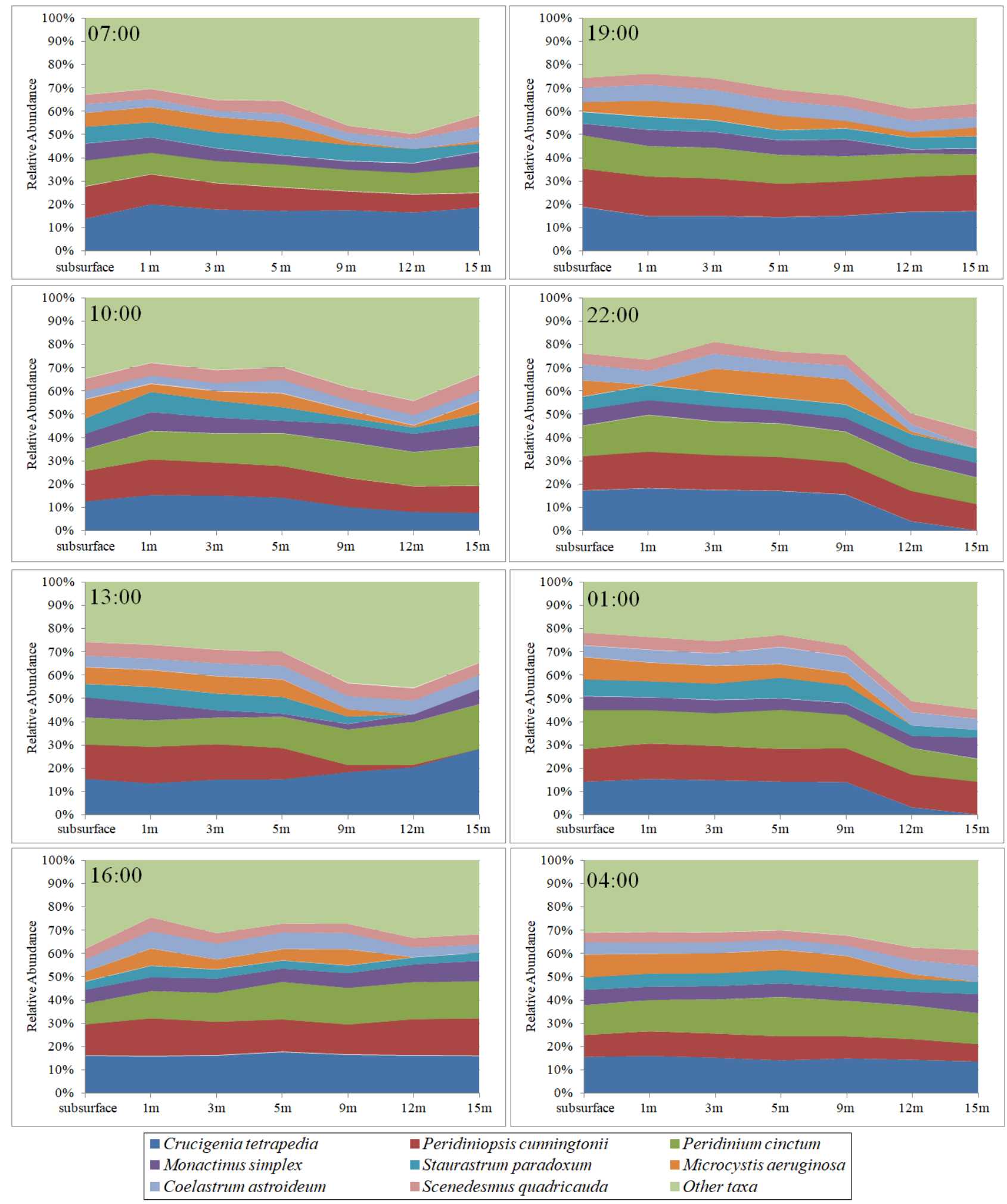

Fig. 7. Relative abundance changes of the dominant species found in Kadıköy reservoir phytoplankton with respect to the months (\% abundance).

Especially, C. tetrapedia being in the first place, $P$. cunningtonii and $P$. cinctum were identified having the highest relative abundance in every sampling hour and in almost all depths. Although M. aeruginosa was identified in the first $5 \mathrm{~m}$, it was not found below $5 \mathrm{~m}$ or identified hardly. In the samplings done at 10:00, 19:00, 22:00 and 04:00, S. quadricauda was found in 12 and $15 \mathrm{~m}$ depths in

higher numbers. C. astroideum was found in high numbers close to the bottom in early morning. $S$. paradoxum was positioned between $1-5 \mathrm{~m}$ while $M$. simplex was found to be vertically distributed almost homogeneously. Hourly identified dominant species and their relative abundances in Kadıköy reservoir are given in Fig. 7. 


\section{Discussion}

Weather and water temperatures measured during the study period were in seasonal normal, but when water temperatures of the surface water and in 1, 3, 5, 9, 12 and $15 \mathrm{~m}$ depths were evaluated according to YSKYY (Surface Water Quality Management Framework), it appeared that they do not exceed I. class water quality values (YSKYY 2015). A pH value between 6.5 and 8.5 is needed to provide a suitable environment for aquatic organisms and to not to pose endangering risks on the life of organisms (Küçükyılmaz et al. 2010). High pH values in particular lead to increase of detrimental effects of ammoniac and nitrogen compounds and therefore it is stated that $\mathrm{pH}$ changes in water is very important in aquatic environments to provide chemical balance thus making sure that aquatic life continues (Küçükyılmaz et al. 2010, Boztuğ et al. 2012). When data taken from the measurements are considered from the perspective of YSKYY, it is found that it does not significantly exceed the I. class quality values in terms of $\mathrm{pH}$ value of the reservoir. Besides being directly related with photosynthesis and respiration and decomposition, dissolved oxygen is also related with light density and temperature (Cunha-Santino et al. 2013). In our study, dissolved oxygen levels were found to be I. class water quality according to YSKYY criteria (YSKYY 2015). In fresh water ecosystems, $250-500 \mu{\mathrm{S} . \mathrm{cm}^{-1}}^{-1}$ conductivity level is suitable for fresh water organisms (Tanyolaç 2011). In Kadıköy reservoir, conductivity levels were measured daily and were found to be suitable for fresh water ecosystems and for the organisms living there. Salinity value is important for drinking water and in our study the values showing the salinity indicate that Kadıköy reservoir is suitable as a freshwater reserve (Tanyolaç 2011).

In this study, 65 taxa have been identified, the highest abundance was determined in the sampling done at 01:00 as 80790 ind. $\mathrm{L}^{-1}$ on the subsurface. In the lake phytoplankton, Chlorophyta $(56.21 \%)$ was found to be dominant followed by Miozoa (15.64\%), Charophyta (9.29\%), Cyanophyta (8.24\%), Euglenophyta $(6.73 \%)$ and Bacillariophyta (3.89\%). Diatoms are represented in low numbers in every sampling hour while Euglonids were higher in number in evening hours under $5 \mathrm{~m}$ depth. Microcystis aeruginosa, which is an eutrophic indicator species, is among the dominant organisms at around $5 \mathrm{~m}$ in the lake phytoplankton. This situation is similar to the results of the study in Ömerli Reservoir performed by Albay and Akçalan (2003). Besides, M. aeruginosa is identified in many reservoir studies like Hasan Uğurlu, Kemer, Çamlıdere, Derbent, Hirfanlı, Ömerli and Kadıköy Reservoir (Fakığlu et al. 2011). This species is also identified in the studies performed in the lakes and rivers of Trakya (Öterler 2013, Öterler et al. 2014, Öterler et al. 2015). Other Cyanophyta group members were not dominant in the reservoir.

In our study area, Chlorophyta is the phytoplankton group that is represented by the highest taxa and organism number. This situation resembles many mesotrophic and eutrophic lakes' phytoplankton compositions (Gönülol \& Obal1 1998b, İşbakan-Taş et al. 2002; Ongun-Sevindik 2010). Among the dominant organisms of the reservoir, C. tetrapedia is a planktonic, cosmopolitan and eutrophic species that is highly seen in lakes and rivers (John et al. 2003). Other Chlorococcales members we came across in our study, Scenedesmus, Monactinus and Pediastrum species, are highly seen in oligomesotrophic reservoirs and eutrophic lakes in our country (Aykulu \& Obal1 1981, Aykulu et al. 1983, Obalı 1984, Gönülol \& Obalı 1998a, 1998b, Atıcı 2001-2002, İşbakan-Taş et al. 2002, Albay \& Akçaalan 2003, Atıcı 2003, Baykal et al. 2004, Kıvrak \& Gürbüz 2005, Özyalın \& Ustaoğlu 2008, OngunSevindik, 2010, Çelekli \& Öztürk 2014).

Among Charophyta, 5 taxa have been identified and most of them are Staurastrum, known as the characteristic of oligotrophic lakes (Rawson 1956, Hutchinson 1967, Wetzel 2001). These species can be seen in many of the oligotrophic and mesotrophic lakes in our country (Baykal et al. 2004, Karacaoğlu et al. 2004, Atıcı et al. 2005, Şahin \& Akar 2007, Ustaoğlu et al. 2010, OngunSevindik 2010, Atıcı \& Alaş 2012).

Miozoa, the $2^{\text {nd }}$ dominant organism group of the reservoir after Chlorophyta was identified as determinant of mesotrophic waters by Rawson (1956): Ceratium hirundinella is common in oligotrophic and mesotrophic waters and Peridinium cinctum and Peridiniopsis cunningtonii are found in high numbers (Rawson 1956, Eloranta 1995, Reynolds et al. 2002). Being identified in water poor in phosphorus, Dinobryon divergens is found in the reservoir in the first 9m depth (Hutchinson 1944, Lee 1980, Sandgren 1988).

There is a strong relation between the physical and chemical features of water bodies and the phytoplankton distribution and structure. The abiotic water conditions show variations naturally throughout the day and over the seasons of the year. These variations which may be related to stratification and mixing of the water column can be either vertical or horizontal. As a result, the availability of light and nutrients for the development of the phytoplankton community result in changes. Stratification, buoyancy, capacity for vertical regulation, light regime and grazing are the factors which have the potential of controlling phytoplankton biomass and species composition (Lopes et al., 2005). It can be said that temperature and especially light are effective in daily vertical changes of phytoplankton in Kadıköy dam. Phytoplanktonic organisms, which are concentrated in 13 meters depending on the amount of light during the day, approach the surface water in order to make more efficient use of light in the evening hours. During the study period, the sunset time in Edirne province was around 21:30. This may explain the detection of high chlorophyll_ $a$ and high cell counts in the sample taken at 22:00, which appears to be a paradox. Phytoplanktonic organisms sink deep into the night with a decrease in the amount of light and temperature. 
In conclusion, the present study provided evidence for a relation with the 24 -h cycle phytoplankton distribution and environmental conditions. The highest values of phytoplankton densities and biomass were found during the second half of a day and for the first $9 \mathrm{~m}$ depth. Phytoplankton taxa without self-regulating capacity and those able to regulate their vertical position were differentially distributed in the segregated layers during the 24-h cycle. The results are regarded as evidence to

\section{References}

1. Akçaalan, R., Young, F., Metcalf, J., Morrison, L., Albay, M. \& Codd, G.A. 2006. Microcystin analysis in single filaments of Planktothrix spp. in laboratory cultures and environmental blooms. Water Research, 40(8): 1583-1590.

2. Akçaalan, R., Köker, L., Gürevin, C. \& Albay M. 2014. Planktothrix rubescens: a perennial presence and toxicity in Lake Sapanca. Turkish Journal of Botany, 38: 782-789.

3. Albay, M. \& Akçaalan, R. 2003. Factors influencing the phytoplankton steady-state assemblages in a drinkingwater reservoir (Ömerli Reservoir, İstanbul). Hydrobiologia, 502(1): 85-95.

4. Atıc1, T. 2001-2002. Sarıyar Barajı Planktonik Algleri Kısım: II- Chlorophyta, Süleyman Demiral Üniversitesi Eğirdir Su Ürünleri Fakültesi Dergisi, 8: 128-151.

5. Atıc1, T. 2003. Sarıyar Barajı Planktonik Algleri Kısım II Chlorophyta. Süleyman Demiral Üniversitesi Eğirdir Su Ürünleri Fakültesi Dergisi, 8: 128-151.

6. Atıcı, T., Obalı, O. \& Calışkan, H. 2005. Su kirliliğinin ve fitoplanktonik alg florasının Bayındır Baraj Gölü'nde kontrolü. Su Ürünleri Dergisi, 22(1): 79-82.

7. Atıc1, T. \& Alas, A. 2012. A study on the trophic status and phytoplanktonic algae of Mamasin Dam Lake (AksarayTurkey). Turkish Journal of Fisheries and Aquatic Sciences, 12: 595-601.

8. Aykulu, G. \& Obal1, O. 1981. Phytoplankton biomass in the Kurtboğazı Dam Lake. Communications de la Facultê des Sciences del"Université de Ankara Serie C 2, 24: 29-45.

9. Aykulu, G., Obal1, O. \& Gönülol, A. 1983. The distribution of the phytoplankton of some lakes of Ankara around (in Turkish with English abstract). Doğa Bilim Dergisi, 7: 277288.

10. Baykal, T., Açıkgöz, İ., Yıldız, K. \& Bekleyen, A. 2004. A study on algae in Devegeçidi Dam Lake. Turkish Journal of Botany, 28: 457-472.

11. Becker, V., de Souza Cardoso, L. \& Huszar, V.L.M., 2009. Diel variation of phytoplankton functional groups in a subtropical reservoir in southern Brazil during an autumnal stratification period. Aquatic Ecology, 43: 285.

12. Boztuğ, D., Dere, T., Tayhan, N., Yıldırım, N., Danabaş, D., Yıldırım, N.C., Önal, A.Ö., Danabaş, S., Ergin, C., Uslu, G. \& Ünlü, E. 2012. Uzunçayır Baraj Gölü (Tunceli) fiziko-kimyasal özellikleri ve su kalitesinin değerlendirilmesi. Adlyaman Üniversitesi Fen Bilimleri Dergisi, 2(2): 93-106.

13. Cunha-Santino, M.B., Bitar, A.L. \& Bianchini Jr., I. 2013. Chemical constraints on new man-made lakes. Environmental Monitoring Assessment, 185: 10177-10190. conclude that temperature and light have effect on daily vertical movements of phytoplankton in Kadıköy reservoir.

Editor-in-Chief note: Burak Öterler is a member of Editorial Board of Trakya University Journal of Natural Sciences. However, he was't involved in the decision process during manucript evaluation.

14. Çelekli, A. \& Öztürk, B. 2014. Determination of ecological status and ecological preferences of phytoplankton using multivariate approach in a Mediterranean reservoir. Hydrobiologia, 740: 115-135.

15. Eloranta, P. 1995. Phytoplankton of the national park lakes in central and southern Finland. Annales Botanici Fennici, 32: 193-209.

16. Fakığlu, Ö., Atamanalp, M. \& Demir, N. 2011. Baraj göllerinde toksik mavi yeşil algler. Ankara Üniversitesi Çevrebilimleri Dergisi, 3(2): 65-71.

17. Guiry, M.D. \& Guiry, G.M. 2017. AlgaeBase. World-wide electronic publication, National University of Ireland, Galway. http://www.algaebase.org (Date accessed: 06 November 2017).

18. Gönülol, A. \& Obal1, O. 1998a. A study on the phytoplankton of Hasan Uğurlu Dam Lake (SamsunTurkey), Turkish Journal of Biology, 22: 447-461.

19. Gönülol, A. \& Obal1, O. 1998b. Seasonal variations of phytoplankton blooms in Suat Uğurlu (Samsun - Turkey) Turkish Journal of Botany, 22: 93-97.

20. Harper, D., Brierley, B., Ferguson, A.J.D. \& Phillips G. 1999. The ecological basis of lake and reservoir management. Hydrobiologia, 395/396: 469 pp.

21. Hindák, F. 2008. Colour Atlas of Cyanophytes. VEDA, Bratislava, $253 \mathrm{pp}$.

22. http://www2.dsi.gov.tr/bolge/dsi11/edirne.htm (Date accessed: 16 August 2017).

23. Huber-Pestalozzi, G. 1982. Das Phytoplankton des Susswasser Teil: 8 E. Schweizerbart'sche Verlagsbuchhandlund (Nagele U. Obermiller), Stuttgart, $539 \mathrm{pp}$.

24. Hutchinson, G.E. 1944. Limnological studies in Connecticut. VII. A critical examination of the supposed relationship between phytoplankton periodicity and chemical changes in lake waters. Ecology, 25: 3-26.

25. Hutchinson, G.E. 1967. A Treatise on Limnology. volume 2, introduction to lake biology and the limnoplankton. New York, John Wiley and Sons, Inc. 1115 pp.

26. İşbakan-Taş, B., Gönülol, A. \& Taş, E. 2002. A study on the seasonal variation of the phytoplankton of Lake Cernek (Samsun-Turkey), Turkish Journal of Fisheries and Aquatic Sciences, 2: 121-128.

27. John, D.M., Whitton, B.A. \& Brook, J.A. 2003. The freshwater algal flora of British Isles, An identification guide to freshwater and terrestrial algae. Cambridge University Press, 700 pp. 
28. Karacaoğlu, D., Dere S. \& Dalkıran, N. 2004. A taxonomic study on the phytoplankton of Lake Uluabat (Bursa). Turkish Journal of Botany, 28: 473-485.

29. Kıvrak, E. \& Gürbüz, H. 2005. Seasonal variations in phytoplankton composition and physical-chemical features of Demirdöven Dam Reservoir, Erzurum, Turkey, Biologia, Bratislava, 60(1): 1-8.

30. Komarek, J. \& Anagnostidis, K. 2005. Cyanoprokariota. 2. Teil: Oscillatoriales. In: Büdel B, Gärtner G, Krienitz L, Schagerl M(eds) Süßwasserflora von Mitteleuropa. Elsevier, Heidelberg, 759 pp.

31. Krammer, K. \& Lange-Bertalot, H. 1986-2004. Bacillariophyceae. 1-4 Teil. Süsswasserflora von Mitteleuropa. H. Ettl, J. Gerloff, H. Heynig, and D. Mollenhauer (editors). Fischer-Verlag, Stuttgart, Germany.

32. Kristiansen, J. \& Preisig, H.R. 2011. Phylum Chrysophyta (Golden Algae). In: The freshwater algal flora of the British Isles. An identification guide to freshwater and terrestrial algae. Second edition. (John, D.M., Whitton, B.A. \& Brook, A.J. Eds). Cambridge: Cambridge University Press, 896 pp.

33. Küçükyılmaz, M., Uslu, G., Birici, N., Örnekçi, N.G., Yıldız, N. \& Şeker, T. 2010. Karakaya Baraj Gölü su kalitesinin incelenmesi. International Sustainable Water and Wastewater Management Symposium, 26-28 October 2010, Konya, Turkey. 445-454.

34. Lee, R.E. 1980. Phycology. Cambridge University Press, Cambridge, $561 \mathrm{pp}$.

35. Lopes, M.R.M., Bicudo, C.E.M. \& Ferragut, M.C. 2005. Short term spatial and temporal variation of phytoplankton in a shallow tropical oligotrophic reservoir, southeast Brazil. Hydrobiologia, 542(1): 235-247.

36. Nusch, E. 1980. Comparison of different methods for chlorophyll and phaeopigment determination. Archiv für Hydrobiologie, 14: 14-36.

37. Obal1, O. 1984. Mogan Gölü fitoplanktonunun mevsimsel değişimi. Doğa Bilim Dergisi, A2, 8(1): 91-104.

38. Ongun-Sevindik, T. 2010. Phytoplankton composition of Çaygören Reservoir, Balikesir-Turkey. Turkish Journal of Fisheries and Aquatic Sciences, 10: 295-304.

39. Öterler, B. 2013. The phytoplankton composition of Kadiköy Reservoir (Keşan Edirne). Trakya University Journal of Natural Sciences, 2(14): 69-76.

40. Öterler, B., Kirgiz, T. \& Albay, M. 2014. Seasonal variations of water quality parameters and algal flora of Tundzha (Tunca) River (Edirne, Turkey). Open Journal of Ecology, 4: 807-819.

41. Öterler, B., Albay, M, Çamur-Elipek, B., Güher, H. \& Kirgiz, T. 2015. Spatial and temporal distribution of phytoplankton in Lake Gala (Edirne/TURKEY). Trakya University Journal of Natural Sciences, 16 (2): 71-80.
42. Özyalın, S. \& Ustaoğlu, M.R. 2008. Kemer Baraj Gölü (Aydın) net fitoplankton kompozisyonunun incelenmesi. E.U. Journal of Fisheries \& Aquatic Sciences, 25 (4): 275 282.

43. Rawson, P.S. 1956. Algal indicators of trophic lake types. Limnology and Oceanography, 1(1): 18-25.

44. Reynolds, C.S. 1988. Funcional morphology and the adaptative strategies of freshwater phytoplankton. In Sandgren, C.D. (ed.), Growth and Reproductive Strategies of Freshwater Phytoplankton. Cambridge University Press, Cambridge: 388-426.

45. Reynolds, C.S., Huszar, V., Kruk, C., Naselli- Flores, L. \& Melo, S. 2002. Towards a functional classification of the freshwater phytoplankton, Journal of Plankton Research, 24(5): 417-428.

46. Round, F.E. 1984. The ecology of the algae. Cambridge Universty Press., Cambridge, 653 pp.

47. Round, F.E., Crawford, R.M. \& Mann, D.G. 1990. The diatoms, biology \& morphology of the genera. Cambridge University Press, 746 pp.

48. Sandgren, C.D. 1988. The ecology of chrysophyte flagellates: their growth and perennation strategies as freshwater phytoplankton. In Sandgren, C. D. (ed.), Growth and Reproductive Strategies of Freshwater Phytoplankton. Cambridge University press, Cambridge: 9-104.

49. Şahin, B. \& Akar, B. 2007. The desmid flora of some high mountain lakes of the Turkish Eastern Black Sea Region. Pakistan Journal of Botany, 39(5): 1817-1832.

50. Takamura, N. \& Yasuno, M. 1984. Diurnal changes in the vertical distribution of phytoplankton in hypertrophic Lake Kasumigaura, Japan. Hydrobiologia, 112: 53-60.

51. Tanyolaç, J. 2011. Limnoloji. Hatiboğlu Yayınları, Ankara, Türkiye, 290 p. (in Turkish).

52. Thornton, K.M., Kimmel, L.B. \& Fonest, E.P. 1990. Reservoir limnology ecological perspectives. New York: J Wiley \& Sons, New York, USA, 246 pp.

53. Ustaoğlu, M.R., Balık, S., Gezerler-Şipal, U., Özdemir, D. \& Aygen, C. 2010. Buldan Baraj Gölü (Denizli) planktonu ve mevsimsel değişimi. E.U. Journal of Fisheries \& Aquatic Sciences, 27(3): 113-120.

54. Utermöhl, H. 1958. Zur Ver vollkommung der quantitativen phytoplankton-methodik. Mitteilungen der Internationalen Vereinigung für Limnologie, 9: 39 pp.

55. Wetzel, R.G. 2001. Limnology, lake and river ecosystems. Third edition. Academic Press, New York, 1006 pp.

56. YSKYY. 2015. Surface Water Quality Management Framework (In Turkish). Official Journal of the publication: Date 15.04.2015, No. 29327. 
